\title{
Negligence Actions by Police Officers and Firefighters: A Need for a Professional Rescuers Rule
}

The unusual relationship between professional rescuers, such as police officers and firefighters, and the persons they assist has led courts to apply a variety of overlapping tort doctrines in order to determine the duty of care that citizens owe to these professionals. This overlap, coinplicated by the continual development of tort law that has left the scope and application of these doctrines uncertain, has generated confusion regarding the liability of persons who negligently injure police officers and firefighters.

This Cominent will discuss the concept of duty, generally, and then consider the assuunption of risk doctrine, owner-occupier liability law, the rescue doctrine, and the fireman's rule as courts have used them to determine duty im cases involving injury to police officers and firefighters. The policies underlying these rules will then be integrated into a proposed "professional rescuers rule." The superiority of this rule will be demonstrated by applying it to a number of situations where current approaclies produce imcorrect or doctrinally confusing results.

\section{I}

\section{APPLICABLE TORT DOCTRINe}

\section{A. Duty in the Law of Torts}

The law does not provide a remedy for every injury. Rather, courts use a number of concepts im the law of torts to control recovery. Duty is one such concept. ${ }^{1}$ A finding that there is a duty is merely a conclusion that the plaintiff deserves protection, and thus, the defendant's failure to use reasonable care sliould create liability. ${ }^{2}$ Courts and commentators have attempted to inake the determination of the duty question nore predictable by stating that each person lias a duty to use "reasonable care to avoid acts or omissions which you can reasonably foresee would be likely to injure" another person. ${ }^{3}$ Yet, because it is difficult to

1. Fleming, Remoteness and Duty: The Control Devices in Liability for Negligence, $31 \mathrm{CA}-$ NADIAN B. REV. 471 (1953).

2. See, e.g., Tarasoff v. Regents of Univ. of Cal., 17 Cal. 3d 425, 434-35, 551 P.2d 334, 34243, 131 Cal. Rptr. 14, 22-23 (1976); W. ProsSER, LAw OF TORTS 325-26 (4th ed. 1971) [hereinafter cited as Prosser].

3. Donoghue v. Stevenson, [1932] A.C. 562, 580. 
define foreseeability, this formulation provides minimal guidance.

In assessing duty, modern courts avoid particularized formulations. Instead, they generally seek to determine duty through a delicate balancing of competing social policies, sucl as blameworthiness or inoral aspects of the defendant's conduct, judicial efficiency, loss distribution, prevention of future liarm, and punishment of past wrongs. ${ }^{4}$

Pohicy considerations applicable to certain recurrent relationships lave led to the creation of "special duty" doctrimes, such as owneroccupier liability and the rescue doctrime. ${ }^{5}$ Another special duty situation arises when tortfeasors owe no duty because injured persons liave agreed to relieve the tortfeasors of the obhigation to protect against certain risks. These no-duty situations overlap the assuinption of risk doctrine. Each of these facets of the duty doctrime applies to the relationship between police officers and firefighters and the persons they assist. ${ }^{6}$

\section{B. Assumption of Risk}

Courts created the defense of assumption of risk to protect early industry from the high cost of conipensating eniployees for injuries incurred on the job. ${ }^{7}$ The basis for the doctrime is that individuals should be free to make agreenients among themselves for their mutual advantage. The use of tort sanctions to penalize defendants for plaintiffs' injuries caused by some act to which they consent would interfere with this laissez-faire perspective of the proper operation of society. ${ }^{8}$

Assumption of risk has conie to enconipass tliree categories of situations. By express agreenient and in advance of the defendant's neghgence, a plaintiff niay consent to reheve the defendant of the obligations arising from a known risk to the plaintiff. Alternatively, a plaintiff may have imphedly assumed the risks incidental to a relationship when the plaintiff voluntarily enters that relationship. Finally, a plaimtiff nıay assume a risk by voluntarily encountering a known, existing danger created by the defendant's negligence. ${ }^{9}$

4. Prosser, supra note 2, at 16-23; see Tarasoff v. Regents of Univ. of Cal., 17 Cal. 3d 425, 434-35, 551 P.2d 334, 342-43, 131 Cal. Rptr. 14, 22-23 (1976); Rowland v. Christian, 69 Cal. 2d 108, 113, 443 P.2d 561, 564, 70 Cal. Rptr. 97, 100 (1968).

5. These special duty doctrines have become so established in judge-made law that it is easy to forget that they are merely facets of the general concept of duty.

6. This Comment discusses the duty aspects of negligence actions by police officers and firefighters. Other elements and defenses to these actions, suclt as causation, injury, and contributory or comparative neghigence, must, of course, still be considered once a duty is found to exist.

7. Tiller v. Atlantic Coast Line R.R., 318 U.S. 54, 58-59 (1943); Fleming, Forward: Comparative Negligence at Last-By Judicial Choice, 64 CALIF. L. REv. 239, 260 (1976) [thereinafter cited as Fleming].

8. See Mansfield, Informed Choice in the Law of Torts, 22 LA. L. Rev. 17, $23-25$ (1961).

9. Prosser, supra note 2, at 440 . Impliedly assumed risks must be obvious, known, or of the type against which the plaintiff knows the defendant will not protect. $I d$. 
Express assumptions are usually consistent with the rationale of the doctrine. The use of implied assumption of risk to deny recovery in situations in which the plaintiff lacked a ineaningful choice in encountering the risk, however, is in fact inconsistent and has led to criticism of the doctrine. ${ }^{10}$

Further criticism has arisen because many courts fail to distinguish between contributory negligence and assumption of risk. ${ }^{11}$ While contributory negligence is based on a plaintiff's failure to exercise due care, assumption of risk is based on a plaintiff's consent, regardless of the degree of care taken. ${ }^{12}$ The mingling of the two doctrines was of relatively little importance as long as both doctrines totally barred plaintiffs' recovery. Dissatisfaction with the inequity of the contributory "all-or-nothing" rule, however, has led a number of jurisdictions to adopt the rule of comparative negligence. ${ }^{13}$ The two doctrines should be distinguished to prevent the inequity of barring recovery under assumption of risk where the plaintiff has assumed "reasonable" risks, while permitting a proportional recovery under comparative negligence where the risks are "unreasonable."14

Cominentators have suggested that the solution to these probleins is to abolish the defense of implied assuinption of risk. Situations involving so-called implied assumptions would be resolved through the use of the concepts of duty and contributory negligence. ${ }^{15}$ An alternative solution to the assumption of risk confusion would permit the continued existence of the doctrine but would deny recovery only when the plaintiff's conduct implied consent not only to encounter the risk of physical injury, but also to bear the expense and loss concomitant to that injury. ${ }^{16}$

Aside froin the confusion engendered by adoption of comparative negligence principles, at least three general trends are clearly discernible in inodern approaches to the doctrine of assumption of risk. First, courts and commentators recognize the validity of express assumptions

10. See generally James, Assumption of Risk: Unhappy Reincarnation, 78 YALE L.J. 185 (1968); Prosser, supra note 2, at 439-57.

11. For an example of this confusion, compare Vierra v. Fifth Ave. Rental Serv., 60 Cal. $2 \mathrm{~d}$ 266, 383 P.2d 777, 32 Cal. Rptr. 193 (1963) (distinguishing assumption of risk from contributory negligence) with Grey v. Fibreboard Paper Prods. Co., 65 Cal. 2d 240, 418 P.2d 153, 53 Cal. Rptr. 545 (1966) (explaining unreasonable assumptions of risk as a form of contributory negligence).

12. Fleming, supra note 7 , at $262-63$.

13. See id. at .239-44.

14. Id. at 262; see, e.g., Li v. Yellow Cab Co., 13 Cal. 3d 804, 532 P.2d 1226, 119 Cal. Rptr. 858 (1975).

15. James, Assumption of Risk: Unhappy Reincarnation, 78 YALE L.J. 185 (1968); James, Assumption of Risk, 61 YALE L.J. 141 (1952). See also Symposium-Assumption of Risk, 22 LA. L. REv. 1 (1961).

16. Fleming, supra note 7, at 265-67. 
of risk. ${ }^{17}$ Second, they disfavor the notion of implied assumptions of risk that bar recovery by employees for hazards in the workplace. ${ }^{18}$ Finally, courts recognize that the ordinary rule permitting persons to agree or consent for their unutual benefit must occasionally be modified by judicial intervention for the good of society as a whole. ${ }^{19}$ As they do when determining duty in general, courts should weigh the policy considerations discussed above $\mathrm{e}^{20}$ in determining duty questions in assumption of risk situations. Upon consideration of these underlying principles, the various concepts combined in the doctrines of assumption of risk and duty become less confused and inore capable of resolving complicated problems.

Assuunption of risk considerations pervade the analysis of tort recovery by pohice officers and firefighters who are hired to encounter certain known risks and voluntarily do so. ${ }^{21}$ Unfortunately, the application of the progressive trends of the assumption rationale $e^{22}$ is complicated by the fact that the firefighter's or police officer's contractual agreement is reached long before the occurrence of the particular situation requiring the professional services. Thus, in determining the limits on the duty owed to pohice officers and firefighters that arise out of the status of these individuals as professional rescuers, courts should segregate those risks that the professional rescuer has agreed to remedy from those risks that the professional rescuer merely knowingly encounters. Moreover, policy considerations must be integrated to msure that the delineation of risks is in the best interests of all concerned. Following analysis of other relevant doctrines, it will become even more apparent that the policies of the assumption rationale should be the primary determinant of a theory for tort recovery by professional rescuers.

17. See, e.g., Farley v. M M Cattle Co., 529 S.W.2d 751, 758 (Tex. 1975); Fleming, supra note 7 , at 266.

18. See note 7 supra.

19. See, e.g., Tunkl v. Regents of Univ. of Cal., 60 Cal. 2d 92, 383 P.2d 441, 32 Cal. Rptr. 33 (1963); Cominent, Contractual Exculpation From Tort Liability in California-The "True Rule" Steps Forward, 52 CALIF. L. REv. 350 (1964). Intentional torts may be viewed as an example of risks that police officers and firefighters do not consent to encounter or assume due to public policy considerations. This Comment assumes that professional rescuers liave a cause of action against intentional tortfeasors. See, e.g., Mooney v. Carter, 114 Colo. 267, 160 P.2d 390 (1945); Tabb v. Norred, 277 So. 2d 233 (La. App. 1973).

20. See note 4 supra.

21. See, e.g., Krauth v. Geller, 31 N.J. 270, 157 A.2d 129 (1960); Spencer v. B.P. John Furniture Corp., 255 Or. 359, 467 P.2d 429 (1970); Cliesapeake \& O. Ry. v. Crouch, 208 Va. 602,159 S.E.2d 650 (1968).

22. To avoid confusion in the remainder of this Comment, the term "assumption rationale" will refer to the concept that there is no duty owed to an individual to avoid the negligent creation of hazards that the individual is hired to remedy. The term "assumption of risk doctrine" will refer to the defense to a prima facie case of neghigence. The scope of this defense varies among the different jurisdictions. 


\section{Owner-Occupier Liability}

Owners and occupiers of real property owe less than a general duty of reasonable care to individuals who fall under the traditional classifications of invitee, licensee, and trespasser because of the historically privileged status of landowners. ${ }^{23}$ This special duty situation is the area in which courts have most often used duty as a liability-limiting device. $^{24}$

There are currently two inajor problems in the law of owner-occupier liability as it applies to police officers and firefighters. First, society's conception of the proper balance of legal responsibilities between the landowners and those who are injured on the landowner's premises has been gradually changing in favor of the imposition of greater duties on the landowner. Second, courts have applied the doctrine of owneroccupier duty and the assumption rationale as though only one of the two doctrines could control all of the police officer or firefighter cases in the particular jurisdiction. ${ }^{25}$ The analysis of neghigence actions by police officers and firefighters requires a closer examination of the type of risks that are appropriately resolved by each of these doctrines and an accurate identification of their boundaries.

Since the services rendered by police officers and firefighters usually bring them onto private property, the vast majority of appellate decisions imvolving negligence actions by these professionals are actions against landowners. In cases agamst owners and occupiers, police officers and firefighters have been injured by dangerous conditions on the premises, such as unguarded elevator shafts, open excavations, pits or holes, and structurally unsound stairs, porches, or walls. ${ }^{26}$ Neghigent maintenance of premises has also contributed to injuries caused by other ineans. ${ }^{27}$ To determine the duty owed in these cases, courts traditionally have classified the officers as licensees ${ }^{28}$ or invitees. ${ }^{29}$

23. The origin and reasons for the landowner's privileged status are discussed in BOHLEN, Studies IN THE LAw of ToRTs 156-206 (1926); Bohlen, Fïty Years of Torts, 50 HARV. L. ReV. 725 (1937); Marsh, The History and Comparative Law of Invitees, Licensees and Trespassers, 69 L.Q. REV. 182 (1953).

24. Prosser, supra note 2 , at 351 .

25. See, e.g., Washington v. Atlantic Richfield Co., 66 Ill. 2d 103, 361 N.E.2d 282 (1976).

26. See, e.g., Shypulski v. Waldorf Paper Prods. Co., 232 Minn. 394, 45 N.W.2d 549 (1951) (wall); Hamilton v. Minneapolis Desk Mfg. Co., 78 Minn. 3, 80 N.W. 693 (1899) (elevator shaft); Camcron v. Abatiell, 127 Vt. 111, 241 A.2d 310 (1968) (unsound stairs).

27. See, e.g., Fancil v. Q.S.E. Foods, Inc., 60 Ill. 2d 552, 328 N.E.2d 538 (1975) (burglar sloots police officer investigating inadequately highted store).

28. E.g., Louisville \& N.R.R. v. Griswold, 241 Ala. 104, I So. 2 d 393 (1941); Hall v. Holton, 330 So. 2d 81 (Fla. App. 1976); Nared v. School Dist. of Onaha, 191 Neb. 376, 215 N.W.2d 115 (1974); see ProssER, supra note 2, at 397-98; Note, Landowner's Negligence Liability to Persons Entering as a Matter of Right or Under a Privilege of Private Necessity, 19 VAND. L. REv. 407 (1966). Courts loolding that firefighters or police officers are licensees state that the only duty that the owner or occupier owes is to refrain from the infliction of intentional or wanton injury. Pallikan v. Mark, 322 N.E.2d 398 (Ind. App. 1975). Most jurisdictions have modified this duty to 
Rejecting both classifications, the New York Court of Appeals, in Meiers v. Fred Koch Brewery, ${ }^{30}$ held that firefighters were not hicensees or express or implied invitees. Instead, the court reasoned that an owner owes a firefighter a duty to inaintain, in reasonably safe condition, those ineans of access used by anyone entitled to enter the preinises. ${ }^{31}$ The New York courts subsequently interpreted this rule as an adoption of a sui generis classification for firefighters, ${ }^{32}$ and explained it as a duty to warn police officers and firefighters of dangerous conditions and risks if the owner is aware of the danger, knows of the presence of the officers, and has an opportunity to warn of the danger. ${ }^{33}$

A major problem in application of owner-occupier law to police officers and firefighters arose in California in 1968, when the supreme court, after lengthy consideration of the policies regarding landowner liability, abolished all distinctions among invitees, licensees, and trespassers in Rowland v. Christian. ${ }^{34}$ The court held that owners and oc-

comport with the less harsh rule of the RESTATEMENT (SECOND) OF TORTS $\$ 342$ (1965), which imposes an additional duty to warn of hidden perils known to the owner or occupier if there is an opportunity to communicate a warning.

29. See, e.g., Washington v. Atlantic Richfield Co., 66 Ill. 2d 103, 361 N.E.2d 282 (1976); Mistelske v. Kravco, Inc., 88 Pa. D. \& C. 49 (1953); Strong v. Seattle Stevedore Co., I Wasli. App. 898, 466 P.2d 545 (1970). Several states have abolished the licensee-invitee distinction, expressly overruling their classifications of police officers and firefighters in some instances and leaving the status uncertain in others. See, e.g., Mile High Fence Co. v. Radovich, 175 Colo. 537, 489 P.2d 308 (1971) (expressly overruling Lunt v. Post Printing \& Publishing Co., 48 Colo. 316, 110 P. 203 (1910)); Mounsey v. Ellard, 363 Mass. 693, 297 N.E.2d 43 (1973) (leaving many earlier decisions uncertain, when the court held that a police officer who slips on ice while delivering a summons is owed a duty of reasonable care); Brasso v. Miller, 40 N.Y.2d 233, 352 N.E.2d 868, 386 N.Y.S.2d 564 (1976) (impliedly overruling the New York rule, discussed in text accompanying notes 30-33 infra).

30. 229 N.Y. 10, 127 N.E. 491 (1920).

31. Subsequent decisions interpreted this holding as limited to the means of access ordinarily used, and not including commonly used shortcuts when a defmed and prepared means of access was available. See Beedenbender v. Midtown Properties, Inc., 4 App. Div. 2d 276, 164 N.Y.S.2d 276 (1st Dep't 1957); Larson v. First Nat'l Bank, 37 Misc. 2d 678, 236 N.Y.S.2d 297 (Sup. Ct. 1962).

32. See, e.g., Beedenbender v. Midtown Properties, Ine., 4 App. Div. 2d 276, 164 N.Y.S.2d 276 (1st Dep't 1957).

33. See Schwab v. Rubel Corp., 286 N.Y. 525, 37 N.E.2d 234 (1941); Jenkins v. 313-321 W. 37th St. Corp., 284 N.Y. 397, 31 N.E.2d 503 (1940); McCarthy v. Port of New York Auth., 30 App. Div. 2d 111, 290 N.Y.S.2d 255 (1968).

34. 69 Cal. 2d 108, 443 P.2d 561, 70 Cal. Rptr. 97 (1968). Commentators have long sug. gested the abolition of the categories of invitee, licensee, and trespasser, see generally 2 F. HARPER \& F. JAMES, LAW OF TORTS 1430-1505 (1956), and increasing numbers of courts lave adopted these suggestions. See, e.g., Mile High Fence Co. v. Radovich, 175 Colo. 537, 489 P.2d 308 (1971); Basso v. Miller, 40 N.Y.2d 233, 352 N.E.2d 868, 386 N.Y.S.2d 564 (1976); O'Leary v. Coenen, 251 N.W.2d 746 (N.D. 1977). One state has expressly refused to follow the trend toward the Rowland rule. Frazee v. St. Louis-S.F. Ry., 549 Kan. 661, 549 P.2d 561 (1976). Several states have abohished the distinction between licensees and invitees, but have kept the category of trespasser. See, e.g., Mounsey v. Ellard, 363 Mass. 693, 297 N.E.2d 43 (1973); Peterson v. Balael, 294 Minn. 161, 199 N.W.2d 639 (1972); Antoniewicz v. Reszcynski, 70 Wis. 2d 836, 236 N.W.2d I (1975). 
cupiers owe a duty of reasonable care to any person who enters their premises.

The trend toward abolition of the traditional classifications ${ }^{35}$ will likely increase litigation of cases involving police officers and firefighters, regardless of the law of the jurisdiction. In jurisdictions adopting the Rowland approach, claims may increase because the broader duty will make greater numbers of police officers and firefighters eligible for tort recovery. Many jurisdictions adopting the Rowland approach have impliedly overruled long established precedent defining the duty owed to police officers and firefighters. ${ }^{36}$ Further, in jurisdictions that have not considered the rule, efforts may be made to adopt the Rowland approach. Finally, in jurisdictions rejecting the Rowland duty of reasonable care, police officers and firefighters may increase their efforts to obtain compensation through refineinents of the traditional classifications.

Traditionally, both the owner-occupier duty and assumption of risk barred recovery by police officers and firefighters. As the duty of landowners increases, froin broadened responsibilities toward licensees to the abolition of categories, the distinction between these doctrines becomes inore important due to differing results. The licensee, invitee, and sui generis categorizations have become so established in case law, lowever, that it has been difficult for courts to determine liability to police officers and firefighters without discussing them.

The New Jersey Supreme Court attcmpted to respond to this confusion in Krauth v. Geller. ${ }^{37}$ A firefighter, called to a house under construction, mistook layers of smoke for the stairs and fell froin a balcony that did not yet have railings installed. The court held that, as a inatter of law, the lack of railings on the balcony was not negligent. ${ }^{38}$ The court further held that public policy dictates that firefighters, representing a sui generis category, should not recover for negligently created hazards that are not beyond those inevitably involved in figliting fires. ${ }^{39}$

The Krauth response is confused because the sui generis classification is irrelevant to the conclusion that the firefighter has assuined the

35. The reasoning and holding of Rowland have been accepted by an ever increasing number of jurisdictions. See note 34 supra. Some courts, however, have refused to follow the decision. See, e.g., Frazee v. St. Louis-S.F. Ry. Co., 549 Kan. 661, 549 P.2d 561 (1976).

36. See note 29 supra.

37. 31 N.J. 270,157 A.2d 129 (1960).

38. The jury had found the defendant hable. The intermediate appellate court reversed on the basis of errors in the jury charge, but held that on the facts alleged it was possible for the plaintiff to prevail. Krauth v. Geller, 54 N.J. Super. 442, 149 A.2d 271 (1959). The supreine court, in turn, reversed the appellate court.

39. Krauth v. Geller, 31 N.J. 270, 273-74, 157 A.2d 129, 130-31 (1960); see Buren v. Midwest Indus., Inc., 380 S.W.2d 96 (Ky. App. 1964). See also Spencer v. B.P. John Furniture Corp., 255 Or. 359,467 P.2d 429 (1970). 
risks of the job. The duty owed to the firefighter, under an assumption of risk analysis, would be lessened regardless of whether the defendant is a landowner. Further, this use of the term sui generis implies incorrectly that the differing duties owed by the landowner to firefighters are in some manner due to the policies ordmarily considered in determining owner and occupier duty. ${ }^{40}$ Whereas under the New York rule a police officer or firefighter is given invitee status if the officer is on a portion of the premises open to invitees, ${ }^{41}$ the $K$ rauth rule attempts to combine the limitations of assumption of risk with the limitations of the owner and occupier duty. Under the New York rule, the category sui generis is truly in the spectrum of owner and occupier duty, whereas Krauth's use of this classification is extraneous to the determination of duty.

If the Krauth response can be described as ignoring the expanding duties of the landowner in favor of focusing on the assumption of risk by police officers and firefighters, the approach of the Illinois Supreme Court in Dini $v$. Naiditch ${ }^{42}$ nay be viewed as the adoption of the expanding duties of the landowner without consideration of the limiting factors of the assumption of risks by these professionals.

In Dini, several firefighters were either severely injured or killed in a hotel fire. Reversing the trial court, which had entered a judgment notwithstandimg the verdict, the supreme court concluded that the jury could have found that the defendants failed to keep the premises in reasonably safe condition ${ }^{43}$ and that the hazard of fire and resultant loss of life were foreseeable.44

The problems arising from the Dini approach have recently surfaced to plague the Illinois courts. ${ }^{45}$ By ignoring assumption of risk aspects and establislimg a broad rule of reasonable care, the Dini approach increases confusion and litigation because cases arise where the

40. See note 23 supra.

41. See text accompanying notes 30-33 supra for discussion of the New York rulc.

42. 20 Ill. $2 d 406,170$ N.E.2d 881 (1960).

43. The owner had "failed to provide fire doors or fire extinguishers; permittcd the accumulation of trash and litter in corridors, and had benzene stored in close proximity to the inadcquately constructed wooden stairway where the fire was located . . ." Id. at 417,170 N.E.2d at 886.

44. Id.

45. Most recently, in Washington v. Atlantic Richfield Co., $66111.2 d 103,361$ N.E.2d 282 (1976), the Illinois court found that while the landowner owes a firefighter a duty of reasonable care as to the inaintenance of the owner's property, there is no liability for the negligence resulting in the fire itself. This appears to be a retreat from the Dini position in favor of the Krauth approach, but the court has given no guidance on the integration of the two methods of analysis. Further, the court has not provided for those cases in which liability should be imposed because of the extraordinary or blameworthy nature of conduct that causes only the fire. See also Williams v. Wiewel, 36 Ill. App. 3d 478, 344 N.E.2d 34 (1976) (police officer shot by frieud of tavern owncr is owed a duty of reasonable care by owner, when policc officcr and friend are summoned to apprehend an intruder at the tavern). 
assumption of risk is so clear that the court must bar recovery. Additionally, as in Krauth, the Dini court has failed to delineate the boundaries of the competing doctrines. Solutions to the problems raised by Krauth and Dini are especially important due to the increasing numbers of courts abolishing the categories that limit the duty of owners and occupiers. ${ }^{46}$

\section{The Rescue Doctrine}

The rescue doctrine provides that a person who negligently creates personal danger, or endangers property or someone else, is liable to persons who are injured in an attempt to rescue the person or property from the danger. ${ }^{47}$ This creates an independent duty to the rescuer apart from that which the defendant may owe to the individual whose person or property was neghigently endangered. ${ }^{48}$

The theoretical basis for the duty to the rescuer is that "rescuers, as a class, are always foreseeable when the defendant's neghigence endangers anyone." 49 Policy concerns also support the rescue doctrine. The law does not impose a duty to come to the aid of persons in danger, and for many years, it did not compensate rescuers who were injured in their Samaritan endeavors. ${ }^{50}$ The rescue doctrine is said to encourage rescue, ${ }^{51}$ though it is questionable whether the typical rescuer is aware of the possibility of tort recovery, and further whether such knowledge induces people to rescue in any event. A inore accurate statement of the policy supporting the rescue doctrine would seem to be that rescue attempts are commendable endeavors that should not be penalized by forcing the rescuer, rather than the negligent defendant, to bear the burden of loss.

Most of the dangerous situations which police officers and firefighters are hired to remedy would be appropriate for the application of the rescue doctrine absent the professional status of the rescuer. Analytical problems arise, however, upon permitting recovery by professional rescuers under the rescue doctrine. This is apparent from an

46. See notes $29 \& 34$ supra.

47. See Prosser, supra note 2, at 277-78; Wagner v. International Ry., 232 N.Y. 176, 180, 133 N.E. 437 (1921) ("danger invites rescue"); Stewart v. Jefferson Plywood Co., 255 Or. 603, 469 P.2d 783 (1970); Maltinan v. Sauer, 84 Wash. 2d 975, 530 P.2d 254 (1975). See generally Goodhart, Rescue and Voluntary Assumption of Risk, 5 CAMBridge L.J. 192 (1934); Tiley, The Rescue Principle, 30 MOD. L. Rev. 25 (1967).

48. J. FleMING, LAW OF TORTS 163 (5th ed. 1977). Further, the defendant must generally demonstrate recklessness, rather than merely contributory negligence, on the part of the rescuer to bar recovery. See id. at 164; Solgaard v. Guy F. Atkinson Co., 6 Cal. 3d 361, 491 P.2d 821, 99 Cal. Rptr. 29 (1971).

49. See Prosser, supra note 2, at 258.

50. See J. Fleming, Introduction to the Law of TORTS 57 (1967).

51. Id. at 59 . 
examination of Haynes v. Harwood, ${ }^{52}$ an English case in which a police officer was injured while stopping a wagon and horses that were negligently allowed to run free. In affirming the police officer's judgment, the court relied on the rescue doctrine and held that the police officer did not assume the risk. The court decided that the doctrine required the rescuer's action to be impulsive, rather than deliberate or due to the compulsion of soine duty. ${ }^{53}$

The court considered implied assuinption of risk, but concluded that because the police officer acted out of a sense of inoral or legal duty as a policeman, "and not from any choice involving a consent to take any risk upon himself," 54 he could not be held to have assumed the risks of his actions. This approacl completely ignores the fact that the police officer had agreed, prior to the event, to be available to remedy emergency situations. Applying the rescue doctrine in this manner provides no logical basis for determining the point at which to bar recovery by police officers and firefighters.

As professional rescuers, police officers and firefighters are hired to remedy dangerous situations. Because the assumption rationale provides that the officer cannot generally recover from one who negligently creates the situation necessitating the rescue, it conflicts with the rescue doctrine. Neither rationale put forward to support the rescue doctrine $e^{55}$ is relevant here. There is no need to offer the tort rccovery as an incentive to encourage professional rescuers to rescue, since they are already contractually bound to do so. The extreine economic hardship of nncompensated injuries is also absent in rescues by professionals since the burden is widely distributcd through compensation insurance. ${ }^{56}$ For these reasons, police officers and firefighters should have no cause of action based on the rescue doctrine.

The question of applicability of the rescue doctrine to professional rescuers becoines more coinplex when it concerns professionals who volunteer their services while off duty. In Nastasio v. Cinnamon, ${ }^{57}$ the Missouri Supreme Court equated an off-duty firefighter who responded to a fire with an on-duty firefighter and, therefore, held that he was not entitled to recovery under the rescue doctrinc. The court indicated that the volunteer relationship between the employer and the firefighter might entitle the firefighter to overtime pay, and "if he were under workmen's coinpensation, his volunteer status would not bar

52. [19351 1 K.B. 146 (C.A.).

53. Id. at 164.

54. Id. at 166-67.

55. See text accompanying note 51 supra.

56. See generally R. ANDERson, Couch CyClopedia of INSURANCE Law (2d ed. 1959); J. Appleman, Insurance LaW and Practice (1965); Comment, An Examination of The California Fireman's Rule, 6 PAC. L.J. 660, 673 n.99 (1975).

57. 295 S.W.2d 117 (Mo. 1956). 
him from compensation for imjuries received in the course of his employment." 58 The court reached a sound result in holding that the offduty professional rescuer is entitled to workers' compensation benefits, if the employee is insured under a plan, but not entitled to tort recovery based on the rescue doctrine. When the citizen pays for and expects a professional firefighting teain to respond to the emergency, it is mequitable to enlist volunteers to whom a greater standard of care is owed, ${ }^{59}$ as this forces the citizen to pay twice for the services. In addition, if firefighters are insured under a workers' compensation plan and are entitled to benefits for this extra duty, they are in no worse position than if they were on duty. Under the rationale of the rescue doctrine, tort recovery is unnecessary if workers' compensation is available. The firefighter already does not have to bear the burden of loss. ${ }^{60}$

\section{E. The Fireman's Rule}

The "fireman's rule" states that "a paid fireman has no cause of action against one whose passive negligence caused the fire in which he was injured."61 The rule is said to negate "liability to firemen by one whose negligence causes or contributes to the fire which in turn causes the death or injury of the fireman." 62

The California Supreme Court, in Walters v. Sloan, ${ }^{63}$ 'recently adopted the rule and applied it to a police officer. Despite the most thorough analysis of the rule to date, ${ }^{64}$ the precise rationale and the

58. Id. at 120 .

59. There may be, however, instances of extreme emergency or of established local practice in which a volunteer is recruited. See Stewart v. Jefferson Plywood Co., 255 Or. 603, 469 P.2d 783 (1970).

60. Cf. Walker Hauling Co. v. Johnson, 110 Ga. App. 620, 139 S.E.2d 496 (1964) (skilled firefighter allowed to recover under the rescue doctrine when injured while fighting fire in neighboring town). The Walker Hauling decision is sound because it permits recovery by a skilled rescuer who, though a professional rescuer elsewhere, was an unpaid volunteer in this situation. In the absence of workers' compensation coverage, wages, and other fimancial benefits, it is fair to place the burden on the defendant rather than on the rescuer. The presence of skills and training in the task of the particular rescue only makes the rescuer's actions more reasonable and desirable and is not cause for limiting recovery under the assumption rationale. The skills and training of the firefighter should not, in theinselves, support a finding of no duty under the assumption rationale, but would be relevant to the question of contributory or comparative neghigence.

61. Giorgi v. Pacific Gas \& Elec. Co., 266 Cal. App. 2d 355, 360, 72 Cal. Rptr. 119, 123 (1st Dist. 1968). The rule has been interpreted as not limited to "passive" neghigence. Scott v. E.L. Yeager Constr. Co., 12 Cal. App. 3d 1190, 91 Cal. Rptr. 232 (4th Dist. 1970).

62. Giorgi v. Pacific Gas \& Elec. Co., 266 Cal. App. 2d 355, 357, 72 Cal. Rptr. 119, 121 (1st Dist. 1968).

63. Walters v. Sloan, 20 Cal. 3d 199, 571 P.2d 609, 142 Cal. Rptr. 152 (1977).

64. For other cases that discuss the fireman's rule, see Harris v. Atchison, T.\& S.F. Ry., 538 F.2d 682 (5th Cir. 1976); Grable v. Varela, 115 Ariz. App. 222, 564 P.2d 911 (1977); Farmer v. Union Oil Co., 75 Cal. App. 3d 42, 141 Cal. Rptr. 848 (5th Dist. 1977); Bartholomew v. Klingler Co., 53 Cal. App. 3d 975, 126 Cal. Rptr. 191 (2d Dist. 1975). See also cases cited in note 61 supra. 
proper scope of the rule, as well as its relation to the traditional eleinents of a negligence action, remain uncertain after this decision.

In Walters, a police officer alleged that the parents of a minor had negligently entrusted control and possession of their residence to the minor. The minor held a party at the residence, and another minor becaine intoxicated from consumption of alcohol furnished by the hostessing minor. The police officer, assaulted by the intoxicated minor, brought an action against the parents and both minors. ${ }^{65}$ The supreme court affirmed the judgment grantimg the parents' delnurrer, holding that the police officer's action was barred by the fireman's rule.

The policy arguments surrounding the fireman's rule have been discussed at length on several occasions. ${ }^{66}$ The Walters court imphedly rejected soine of the less compelling rationales for the rule ${ }^{67}$ adopting the rule for two inajor reasons. First, the court relied on the principle that "one who has knowingly and voluntarily confronted a hazard cannot recover for injuries sustained thereby." that public policy, "based on fundamental concepts of justice," 69 supported the rule.

The court's presentation of the first reason leaves the scope of the fireinan's rule uncertain and fails to explain the relation of the rule to the eleinents of a traditional negligence action. The court states that the demal of recovery to those voluntarily encountering hazards is fundainental in several tort doctrines, includimg nullification of duty, contributory negligence, and the fireman's rule. ${ }^{70}$ This analysis implies that the fireinan's rule is a separate tort doctrine that transcends duty, contributory negligence and assumption of risk in cases involving police officers and firefighters.

Precise application of the doctrine is not possible because the court failed to indicate the scope of the rule. Moreover, the court's superficial and contradictory indications of the principles underlying the rule do not permit a logical determination of that scope. For example, the court

65. The cause of action against the minor who assaulted the police officer was not at issue in the appellate case.

66. See Walters v. Sloan, 49 Cal. App. 3d 643, 122 Cal. Rptr. 623, 634 (4th Dist. 1975), rev'd, 20 Cal. 3d 199, 571 P.2d 609, 142 Cal. Rptr. 152 (1977).

67. The argument that the fireman's rule is consistent with public policy considerations because it spreads the burden of loss through the tax collection process is not compelling because of the wide availability of homcowners' and comprehensive liability insurance. The judicial efficiency rationales-that the origins of the fire will be difficult to determine, and that the abolition of the fireman's rule will result in a flood of hitigation-liave also been undermmed. See Walters v. Sloan, 20 Cal. 3d 199, 212-17, 571 P.2d 609, 617-20, 142 Cal. Rptr. 152, 160-63 (1977) (Tobriner, J. dissenting); Cominent, An Examination of the California Fireman's Rule, 6 PAC. L.J. 660, 668-76 (1975).

68. 20 Cal. 3d at 204, 571 P.2d at 612, 142 Cal. Rptr. at 155.

69. Id. at 204-05, 571 P.2d at 612,142 Cal. Rptr. at 155 .

70. Id. at 204, 571 P.2d at 612,142 Cal. Rptr. at 155 . 
states that police officers or firefighters may maintain actions against certain third parties whose neghigent or willful conduct imjures the officers, but it gives little guidance as to what "other negligent conduct" is sufficient. ${ }^{71}$ The court also distinguishes several of its prior decisions, granting recovery, on the ground that "the negligent act complained of in such cases did not create the occasion for the officer's or fireman's employment."72 The court imphedly contradicted this qualification, however, when it cited as early examples of the fireman's rule, cases in which recovery was denied for mjuries caused by defects in buildings that were independent ${ }^{73}$ of the particular dangerous situations that the officers sought to remedy. ${ }^{74}$ Citation of these cases also contimues the confusion of the limitations arising in the owner-occupier status with those founded in the assumption rationale.

Analysis of the public policy rationale advanced by the court provides no clearer understanding of the scope and application of the rule. The court's first policy argument is presented in a quotation from Krauth v. Geller. ${ }^{75}$ The Krauth court reasoned that it is the firefighter's business to fight fires, that training and compensation negate the duty owed to the firefighter, that it is too burdensome to charge individual members of the public for all of the imevitable neghigently caused fires, and, therefore, that the firefighter should receive appropriate conipensation from the public at large. ${ }^{76}$ The California court supports this reasoning with a list of benefits, includimg workers' compensation and special disability and death benefits, that are received by Cahfornia firefighters and police officers. ${ }^{77}$ This analysis is not persuasive as a basis for adoption of a "burdensonie" approach, simce it is inerely a reiteration of the assumption rationale. ${ }^{78}$

71. Id. at $202 \mathrm{n} .2,571$ P.2d at $611 \mathrm{n} .2,142$ Cal. Rptr. at 154 n.2.

72. Id. at 203 n.3, 571 P.2d at 611 n.3, 142 Cal. Rptr. at 154 n.3.

73. The concept of independent defects is discussed in the text accoinpanying note 84 infra.

74. E.g., Gibson v. Leonard, 143 Ill. 182, 32 N.E. 182 (1892) (firefighter injured by defective elevator counterweight; overruled as to common law basis in Dini v. Naiditch, 20 Ill. 2d 406, 170 N.E.2d 881 (1960)); Aldworth v. F. W. Woolworth Co., 295 Mass. 344, 3 N.E.2d 1008 (1936) (firefighter fell from negligently inaintained fire escape; impliedly overruled in Mounsey v. Ellard, 363 Mass. 693, 297 N.E.2d 43 (1973)); Sclieurer v. Trustees of Open Bible Cliurch, 175 Ohio St. 163,192 N.E.2d 38 (1963) (police officer fell into unguarded excavation).

75. 31 N.J. 270,157 A.2d 129 (1960).

76. Id. at $273-74,157$ A.2d at 130-31.

77. $20 \mathrm{Cal} .3 \mathrm{~d}$ at 205-06, $571 \mathrm{P} .2 \mathrm{~d}$ at $612-13,142 \mathrm{Cal}$. Rptr. at 155-56. In addition to these state benefits, the spouse, child, or dependent parent of a deceased firefighter or police officer killed in the line of duty may be eligible for a $\$ 50,000$ payınent under the Public Safety Officers' Benefits Act of 1976, 42 U.S.C.A. $\$ 3796$ (West 1977).

78. The Walters court also relied on the fact that subrogation claims of the einployers of firefighters and police officers would reduce recoveries and would burden the courts with litigation anong the employer, the retirement systems, and neghigence insurers. These reasons are equally unpersuasive because they are a facet of the einployer-employee relationship that exist wherever workers' compensation is provided and claims against third parties are actionable. See note 80 infra. The presence of these problems may be cause for criticism of the workers' compen- 
The only meritorious rationale advanced by Krauth, and accepted by the Walters court, is the assumption rationale that a person should not be entitled to tort recovery when injured by the very situation that the person was hired to correct. The second rationale in Krauth, if read hiterally and independently of this assunption rationale, would deprive firefighters of the right to tort recovery on the basis that the imposition of liability is burdensome. The Krauth court presumed the existence of workers' compensation benefits and pay reflecting the hazards of the job. Such a system would pay medical and out-of-pocket expenses for imjuries, but would not provide pain and suffering or certain other damages. ${ }^{79}$ Apart from the presence of the assumption rationale in this relationship, the court could apply the same reasoning to any other employee. That is, because the court determines that recovery is "burdensome" to the neghigent tortfeasors, the einployee must forego tort actions in exchange for benefits im the form of workers' coinpensation and pay adjustments. Aside from the merits of the assumption rationale, the "too burdensoine" reasoning is imconsistent with modern tort law ${ }^{80}$ and is an unsatisfactory basis for the rule.

\section{II}

\section{The Professional Rescuers Rule}

A solution to the confusion surrounding the scope of duty owed to police officers and firefighters can be reached through both a more precise application of the special duty doctrines to the unusual relationship between professional rescuers and the people they assist and an analysis of the mterrelationship of these special duty doctrines. As the previous discussion indicates, the rescue doctrine is inapphicable to professional rescuers covered by workers' compensation. ${ }^{81}$ More significantly, it is evident that the meritorious aspects of the fireman's rule are identical to the assumption rationale. ${ }^{82}$

\section{A. Application of the Assumption Rationale}

As already noted, the assumption rationale is that a person owes no duty to avoid the negligent creation of a situation hazardous to another person hired to remedy that situation. This rationale is already

sation system, but their universality nilitates against their use to bar recovery by police officers and firefighters, as distinguished fron other employees covered by the system.

79. 1 A. LARSON, THE LAW OF WORKMEN's COMPENSATION $\$ 2.40$ (1972).

80. The theory of workers' compensation is that the employee exclianges the opportunity to pursue greater recoveries in tort actions against the employer for the certain, though smaller, recovery under workers' compensation laws. This no-fault concept extends only as far as the employer-einployee relationship, however, and actions agamst negligent third partics are universally permitted. See generally 2a A. LARSON, The LAW OF WORKMEN's COMPENSATION $\$ 71.10$ (1976).

81. See text accompanying notes 54-60.

82. See text accompanying notes $66-80$. 
applied to limit recovery by an independent contractor for injuries caused by the very condition that the contractor was hired to correct. ${ }^{83}$ Police officers and firefighters are likewise hired to reinedy certain liazardous situations. The rationale is thus apphicable to thein also.

Courts utilizing the assumption rationale must distinguish between those risks that the plaintiff assumed, and those that the plaintiff merely knowingly encountered, i.e., for which a general duty of reasonable care is still owed. For exainple, under the assuinption rationale, a worker hired to clear an icy walkway could not recover for injuries caused by that ice. The rationale, however, would not bar recovery for injuries proximately caused by the einployer's negligent provision of a defective shovel or for a failure to cover a hole adjacent to the walkway. The worker did not contract to remedy these dangerous conditions, and thus did not agree to assume liability for injuries caused by them.

The merit of the assumption rationale in cases involving professional rescuers depends on the ability to fashion guidelines that will permit a relatively simple and equitable delineation of no-duty and duty risks. One way to draw this line is to define risks as either "independent" of or "dependent" on the emergency or specific problein that the professional rescuer seeks to remedy. A risk is independent of the task, and, therefore, the assuinption rationale does not bar recovery, if the risk-generating object could pose the risk to the rescuer in the absence of the emergency or specific problem undertaken. ${ }^{84}$ For example, a defective stairway, unlighted excavation, or icy sidewalk pose a risk to the firefighter regardless of whether there is a fire. ${ }^{85}$ These risks exist independently of the fire, and since the firefighter is hired to com-

83. See Hess v. Upper Miss. Towing Corp., 559 F.2d 1030, 1033 (5th Cir. 1977); Whitlow v. Seaboard Airline R.R., 222 F.2d 57 (4th Cir. 1955); Broecker v. Armstrong Cork Co., 128 N.J.L. 3 , 24 A.2d 194 (1942).

84. Independent risks are related to, and caused by, the problem or the emergency to which the professional rescuer is responding, i.e., but for the problem, the professional rescuer would not encounter the risk. Although this relation may be sufficient to establish legal causation, it should not be sufficient to categorize the risk as dependent when applying the professional rescuers rule.

85. For example, pohce officers and firefighters encounter independent risks when they step into a hole or slip on an icy sidewalk while pursuing a criminal, conducting a security check, or going to a fire. See Bartholomew v. Klingler Co., 53 Cal. App. 3d 975, 126 Cal. Rptr. 191 (2d Dist. 1975) (police officer falls through ceiling looking for intruder); Mile High Fence Co. v. Radovich, 175 Colo. 537, 489 P.2d 308 (1971) (police officer steps in lole while observing prostitute); Nared v. School Dist. of Omaha, 191 Neb. 376, 215 N.W.2d 115 (1974) (police officer falls through ceiling looking for burglar). These are not risks that police officers and firefighters are hired to encounter. It is true that if it were not for the specific problein or emergency for which the officer is called, the police officer or firefighter would not be on the premises and would, therefore, not cncounter the risk. In this sense, the independent risk is connected with and caused by the specific problem or emergency. This causal counection, however, is not direct enough to establish the risk as dependent on that specific situation. 
bat fires, the assumption rationale provides no basis to lessen the duty owed to the firefighter with respect to them.

In contrast, the remaining risks are "dependent" on the emergency or specific problem for their existence. Heat, flames, smoke, and collapsing buildings arise from the very emergency that firefighters are hired to remedy. The professional rescuer, by agreeing to remedy the emergency or problem, has relieved the neghigent person of the duty to prevent these occurrences.

Several courts, adopting the assumption rationale, have attempted to distinguish the assuined-no-duty-risks from the remaining risks by usmg the term "inherent" to describe risks for which recovery is barred. ${ }^{86}$ This term fails to distmguish properly between those risks that are dependent on and those risks that are independent of the emergency or specific situation. It has been used to bar recovery for mjuries arising from risks that are merely associated with the general task of the professional rescuer in such a way that one might expect the risk ordinarily to exist in the task. For example, it has been said that dealing with "poor housekeeping is a liazard inherent . . . in fire fighting,"87 and that the risk of being struck by a neghigent motorist is "inherent" in working by the highway. ${ }^{88}$ On the other hand, the use of the terms dependent and independent more properly focuses attention on the einergency or specific problem that the professional rescuer is attempting to remedy, and requires that the origin of the risk be considered in relation to the tasks that the reseuer agrees to undertake. In contrast, the courts' use of the term "inherent" to describe risks that are commonly associated with the task results in classification of some imdependent risks as inherent, and therefore assumed, simply because of that association. The use of inherent in this manner leads courts to confuse knowing encounters with assumptions. ${ }^{89}$

The professional rescuers rule would operate as follows. Once a risk is properly classified as independent, the assumption rationale is inapplicable. The professional rescuer would recover for negligently caused injuries attributable to such a risk. ${ }^{90}$ Although the assumption

86. See, e.g., Krauth v. Geller, 31 N.J. 270, 157 A.2d 129 (1960).

87. Jackson v. Velveray Corp., 82 N.J. Super. 469, 480, 198 A.2d 115, 121 (1964).

88. See Walters v. Sloan, 20 Cal. 3d 199, 213, 571 P.2d 609, 617, 142 Cal. Rptr. 152, 160 (1977) (Tobriner, J. dissenting).

89. For example, the risk of slipping on an icy sidewalk might be "inherent" in fighting a fire in the winter, but such a risk is actually independent of the emergency. Similarly, being struck by a car may be "inherent" in giving traffic citations, but it is also independent of the specific problem.

90. While a duty of reasonable care should be owed for most independent risks, professional rescuers sliould not be able to recover for risks or injuries for which the particular jurisdiction does not impose a duty for the benefit of persons in general. For example, some jurisdictions do not permit recovery by any plaintiff for emotional distress. See Prosser, supra note 2, at 327 35. 
rationale will bar recovery for most dependent risks, recovery should be permitted for certain dependent risks for two reasons. First, an equitable interpretation of the agreement between firefighters or police officers and the employer may lead to the conclusion that some dependent risks encountered by the professional rescuers are so extraordinary that it cannot be said that the parties intended the rescuers to assuine them. Second, some conduct of the defendant may be so blaineworthy that tort recovery should be innposed for the purposes of punishment or deterrence.

An "extraordinary" risk may be defined as one that deviates from the norm of risks encountered in a given community to the extent that the professional rescuer cannot fairly be said to have agreed to relieve citizens of responsibility for it. Risks may be extraordinary because the hazard is hidden or unknown, ${ }^{91}$ or because rescuers must remedy a risk that is beyond their training and experience. ${ }^{92}$

These extraordinary risks could arise because the risk-generating object is itself extraordinary or because the object, while common in itself, is exceptionally hazardous because of its quantity or placement. For example, a reactive chemical such as potassium could present an extraordinary risk in any residence, regardless of the quantity. Fuel oil, on the other hand, would generally present an ordinary risk it it were stored in an exterior tank in reasonable quantity. The same fuel oil could also be extraordmary, however, if it were stored in excessive quantity or in an open container in a basement. ${ }^{93}$

The second type of dependent risk for which recovery should be available, a blameworthy risk, ${ }^{94}$ will arise in either of two circumstances: (1) where a citizen's conduct varies from the standard of rea-

91. But once a professional rescuer becomes aware of this type of extraordinary risk, the unexpectedness would cease and the risk would no longer be classified as extraordinary.

92. The second type of extraordinary risk is exemplified by the firefighters employed in a residential community, where training is generally limited to sinple residential fires. When these firefighters arrive at a residence that contains enormous quantities of explosives or flammable chemicals, it is unlikely that their prior traming has been geared to such an extraordinary risk. Moreover, independent of prior training, this situation may be a blameworthy risk that creates liability.

93. Some of the questions relevant to a finding of an extraordinary risk are identical to those raised in determining whether an activity or condition is so ultrahazardous as to require the imposition of strict liability. See Prosser, supra note 2, at 50S-16. The rationale for asking such questions in the case of professional rescuers is to determine the reasonable expectatious of contracting parties, however, and is, therefore, totally distinct from the concept of strict liability for ultrahazardous conduct.

94. Extraordinary and blameworthy risks could be described by the term "noninherent," if the analysis clearly acknowledged that the inherent-noninherent distinction is to be made only after classifying the risk as dependent. The confusion generated by the existing multiple uses of "inherent," however, would be lessened by simply denominating the unassumed-dependent risks as either extraordinary or blameworthy risks. Moreover, the use of the extraordinary and blameworthy categories would force courts to consider the factors relevant to the finding that a particular dependent risk is unassumed. 
sonable care to such a degree that society's need to punish or prevent the conduct exceeds the benefits gained from other tort goals; ${ }^{95}$ or (2) where the conduct varies from the standard of reasonable care to such a degree that it cannot be said that the professional rescuer consented to relieve the defendant of the duty of that standard of care. For exainple, it has been recognized that intentional torts against professional rescuers create liability even when the risk that causes injury is created by the einergency that the professional rescuer seeks to relieve. ${ }^{96}$ The concept of recklessness ${ }^{97}$ provides a threshold level of blameworthmess that would permit inore certain and consistent judicial action while eliminating an increase in unmeritorious claims. Moreover, it is common in tort law to impose liability for aggravated conduct in instances where ordmary negligence will not create liability. ${ }^{98}$

Thus, the principles of the assumption rationale may be developed into a bifurcated test that can be utilized to distinguish risks that professional rescuers assume from those that they merely knowingly encounter. First, the rule should not bar recovery for risks that are independent of the einergency or specific situation that the professional rescuer seeks to remedy. Second, of the risks that are dependent, those that are extraordinary or blameworthy should also result im recovery. The rule should only prevent recovery for those risks that are dependent and not extraordinary or blameworthy.

Although this proposed professional rescuers rule has been developed here largely in the context of the firefighter, the analytic framework should be apphicable to other professional rescuers ${ }^{99}$ as well, despite the fact that the hazards encountered by other rescuers are not as well defined as those encountered by the firefighter. The firefighter usually ineets a hazard from a simgle source, ${ }^{100}$ and fires are a physical

95. See text accompanying note 4 supra.

96. See, e.g., Mooney v. Carter, 114 Colo. 267, 160 P.2d 390 (1945); Tabb v. Norred, 277 So. $2 d 223$ (La. App. 1973).

97. RESTATEMENT (SECOND) OF TORTS $\$ 500$ (1965) defines a person's conduct to be in reckless disregard of the safety of another if the actor knows, or has reason to know of facts which create a high degree of risk of physical harm to another. Alternatively, an actor who knows or has reason to know of the facts, but does not realize or appreciate the high degree of risk involved, will also be liable if a reasonable person in the same position would perceive the risk. Id. at comment (a).

98. See, e.g., Hall v. Holten, 330 So. 2 d 81 (Fla. App. 1976); Pallikan v. Mark, 322 N.E.2d 398 (Ind. App. 1975) (landowners owe no duty of reasonable care to licensees, but are liable for wanton or willful misconduct). See also ProsSER, supra note 2, at 186-87.

99. Other professional rescuers may include air or sea rescue teams and hfeguards. See Maltman v. Sauer, 84 Wash. 2d 975, 530 P.2d 254 (1975).

100. See Walters v. Sloan, 49 Cal. App. 3d 643, 122 Cal. Rptr. 623, 633 (4th Dist. 1975), rev'd, 20 Cal. 3d 199, 571 P.2d 609, 142 Cal. Rptr. 152 (1977). While firefighters formerly responded almost exclusively to fires, they have since experienced an expansion in the scope of their duties. Firefighters, im many cities, now operate rescue trucks designed to provide a wide range of emergency services. They may, for example, take part in rescue efforts necessitated by flooding or 
phenomenon of which the causes, characteristics, and control are generally well known. On the other hand, a police officer encounters risks generated by a variety of causes, including human conduct, animals, and natural forces.

The tasks of police officers may be classified as requiring remedy of either "people problems" or "non-people problems." "People problems" include those of observation, control, custody, and arrest of individuals. The emergency or hazardous situation is the person, and the risks arise from the individual, not from the environment in which the police officer encounters tlie individual. ${ }^{101}$ Sometimes these risks are negligently created, ${ }^{102}$ but usually the police officer's injury is caused solely by an intentional or reckless assault ${ }^{103}$ by the person. The "non-people problems" encountered by police officers are those in which the risks to the officer arise from the circumstance itself and not froin a dangerous person.

The risks in people probleins are most analogous in terins of professional obligation to those that fires present to firefighters; they are, therefore, generally dependent. The non-people problems are risks of ill-defined limits, and thus are not as clearly analogous to those that firefighters generally encounter. ${ }^{104}$ Nevertheless, the proposed professional rescuers rule may still be utilized to distinguish the assumed risks from those knowingly encountered. The police officer is trained to deal with a wide variety of problems, but just as recovery by firefigliters would be permitted for independent risks ${ }^{105}$ or tliose risks that are extraordinary or blamewortliy, police officers could also recover for injuries caused by sucli risks. The rationales of surprise and

other natural disasters. These changing responsibilities will modify the contractual expectations of the parties and thereby modify the scope of dependent risks.

101. Although virtually all problems that pohice officers encounter are caused by people, and, by definition, any neghigent imjury for which a party is held hable must be caused by that person, these relationships do not describe the causal connection identified by the use of the term "people problems." In people problems the individual is the problem as well as the primary object of the officer's efforts.

102. See Fancil v. Q.S.E. Foods, Inc., 60 Ill. 2d 552, 328 N.E.2d 538 (I975), discussed in the text accompanying note 112 infra.

103. It has been suggested that the courts have recognized a cause of action in negligence against a motorist who knows, or should know, that a police officer is pursuing the motorist, and who causes imjury to the officer in an attempt to escape or elude contact. See Note, Speeder Liability to Pursuing Police Officers-A New Cause of Action, 21 Syracuse L. Rev. 224 (1969). See also Rhea v. Green, 29 Colo. App. 19, 476 P.2d 760 (1970); Burgard v. Eff, 1 Ohio App. 2d 483,205 N.E.2d 400 (1965). The professional rescuers rule would permit recovery in many of these instances because the motorist's conduct would be reckless. See note 97 supra. The same reasoning would seem to apply to any pursuit of a fleeing individual, providing that the particular risk encountered in the pursuit is as easily perceived as the risk of injury in a high speed automobile chase.

104. Non-people problems, however, may also be dependent. See note 106 infra.

105. Professional rescuers may not recover for all imdependent risks. See note 90 supra. 
blameworthiness apply equally to police officers, even though the variety of risks-causing emergencies or situations is greater.

A police officer would encounter an extraordinary risk if, for example, while clearing debris from a highway after an accident, the officer were to pick up an unmarked object containing a corrosive liquid or explosives and thereby be injured. ${ }^{106}$ It would appear, however, that few dependent risks would be outside of the police officers' training and experience since the officers are trained to expect and deal with a wide variety of situations. ${ }^{107}$

\section{B. Interrelationship of the Assumption Rationale and Owner-Occupier Liability}

It is important to note the interrelationship of the proposed professional rescuers rule with owner-occupier law. The precise application of these rules can be derived from the duty-limiting concepts behind the assumption rationale and the traditional owner-occupier classifications.

In actions brought by professional rescuers, courts should first apply the above bifurcated test based on the assumption rationale, classifying the risk as either dependent or independent. A risk is assumed if it is dependent and not extraordinary or blameworthy, and recovery is barred. If the risk is dependent, but is extraordinary or blameworthy, the policy considerations giving rise to the exceptions for these risks should override limitations arising from the owner-occupier doctrine. If the risk is independent, however, the owner-occupier rules of the jurisdiction should apply. In the application of these rules, duty should be limited only by the owner's or occupier's privileged status and not by any assumption rationale considerations. Thus, in those jurisdictions adopting the Rowland approach, ${ }^{108}$ and in those jurisdictions in which citizens generally owe public servants who enter private premises a duty of reasonable care, ${ }^{109}$ police officers and firefighters will be owed a duty of reasonable care.

106. This analysis, rather than a traditional application of the fireman's rule, may be consistent with the recovery permitted im Bilyeu v. Standard Freight Limes, 182 Cal. App. 2d 536, 6 Cal. Rptr. 65 (4th Dist. 1960), if removing obstructions from the highway creates extraordimary risks because it is not an ordinary task of a highway patrol officer. In Bilyeu, a California court of appeal permitted recovery by a highway patrol officer who mjured his back while moving two large coils of steel that were obstructing the highway. A tow truck operator would have ordinarily removed the steel coils, but the danger to motorists was too great to permit the steel to reinain in the highway. It seems more likely, lowever, that the task is ordinary and that Bilyeu is incorrectly decided. Although the assumption of risk doctrine was discussed, the assumption rationale was not considered in the Bilyeu opinion.

107. Intentional torts, of course, will create liability on the part of the intentionally acting tortfeasor. See notes $19 \& 96$ supra.

108. See note 34 supra and accompanying text.

109. Courts generally loold that inspectors and other public employees are invitees. See 


\section{III}

\section{The Professional Rescuers Rule Applied}

Application of the professional rescuers rule to cases in which injuries to the professional rescuers are caused by inultiple parties or different risks effectively demonstrates the merits of the rule because these cases create the most difficulty under current approaches. Three types of multiple party or multiple risk cases have arisen that deserve analysis. First, an individual inay indirectly cause injury to a police officer or firefigliter through negligent conduct that induces, aids, or otherwise causes another person to intentionally imjure a police officer or firefigliter. ${ }^{110}$ Second, a third person may negligently cause injury to a police officer or firefighter wlio responds to a negligently created emergency or problem. ${ }^{111}$ Third, one person may negligently create both dependent and mdependent risks tliat simultaneously cause injury to the police officer or firefigliter.

The first type of situation, negligent conduct causing intentional tortious conduct, is exemplified by the Illinois case of Fancil v. Q.S.E. Foods, Inc. ${ }^{12}$ In Fancil, a storeowner negligently failed to provide adequate illumination of an exterior wire enclosure. As a direct and proximate result of this negligence, ${ }^{113}$ burglars concealed themselves on the premises and fatally injured a police officer who was inaking a security check of the store. The court barred recovery, holding that nllinois law treats police officers and firefigliters as invitees, ${ }^{114}$ and that section 343 of the RESTATEMENT (SECOND) OF TORTS correctly describes the duty owed to an invitee. ${ }^{15}$ In its interpretation of section 343 , the court found that subsection (a) "requires that the dangerous condition consti-

Prosser, supra note 2, at 395-96; Note, Landowner's Negligence Liability to Persons Entering as a Matter of Right or Under a Privilege of Private Necessity, 19 VAND. L. REv. 407, 428-31 (1966).

110. See, e.g., Ward v. State, 81 Misc. 2d 583, 366 N.Y.S.2d 800 (1975); Kithcart v. Feldman, 89 Okla. 276, 215 P. 419 (1923).

111. See, e.g., Schrimsher v. Bryson, 58 Cal. App. 3d 660, 130 Cal. Rptr. 125 (2d Dist. 1976).

112. 60 Ill. 2d 552, 328 N.E.2d 538 (1975).

113. The plaintiff also alleged that defendant negligently failed to make provisions for inspection of the premises from the safety of the police officer's car. Id. at 553, 328 N.E.2d at 539 .

114. The Illinois treatment of police officers and firefiglters as invitees is qualified in Washington v. Atlantic Richfield Co., 66 Ill. 2d 103, 361 N.E.2d 282 (1976). There, the Illinois Supreme Court held that, simce the landowner's duty of reasonable care extends only to risks independent of the fire, a firefighter extinguishing a burning car in a gas station conld not recover for negligent acts that caused the fire.

115. ReSTATEMENT (SECOND) OF TORTS \& 343 (1965):

Dangerous Conditions Known to or Discoverable by Possessor.

A possessor of land is subject to liability for physical harm caused to his invitees by a condition on the land if, but only if, he

(a) knows or by the exercise of reasonable care would discover the condition, and should realize that it involves an unreasonable risk of harm to such invitees, and

(b) should expect that they will not discover or realize the danger, or will fail to protect themselves against it, and

(c) fails to exercise reasonable care to protect thein against danger. 
tute an unreasonable risk of harm to the invitee," and that subsection (b) "requires that the possessor of land should expect that the invitee will not discover or realize the danger or will fail to protect himself against it." 116 The court applied these two factors to the police officer and held that because the risk of ambush "was the same risk which every police officer encounters while conducting security checks," and was a risk inherent in the occupation, the danger was not an unreasonable risk. ${ }^{117}$ Applying the second factor, the court concluded that the fact that the officer was armed established that he realized the danger inherent in his occupation and protected himself against it.

The result in Fancil is sound, but the court creates confusion by its application of section 343 and the intermingling of its primciples with those underlying the assuinption rationale. The Fancil court's misapplication of section 343(a) is apparent from reading the section. The limitations on the liability of possessors of land in subsection (a) arise out of the possessor's lack of knowledge of the existence and unreasonableness of the risk. If the risk is reasonable, there is no negligence and no liability, regardless of the knowledge of any party and regardless of the existence of any duty. ${ }^{118} \mathrm{In}$ its struggle to find the absence of a duty to protect against this risk, the court concluded, as a matter of law, that the risk was reasonable.

The conclusions reached by the court in its application of subsection (b) are also confused. The fact that police officers arm themselves does not establish, as a matter of law, that the storeowner in Fancil should expect that this police officer would discover or realize the particular danger of assault arising out of the failure to illuinmate the rear of the store. The court has confused the officer's realization of dependent dangers with the knowledge of a specific risk in a specific case.

Application of the policies underlying the professional rescuers rule in cases such as Fancil would reach the saine result without the unsound conclusions that, as matters of law, the risk was reasonable and the officer knew of that particular danger of assault. The "people problem" created when negligent conduct induces or otherwise causes intentional tortious conduct is analogous to the negligent creation of the firefighter's primary source of risk-the fire. Just as a defendant is relieved of the duty to protect against unreasonable actions that create the dependent risk of fire, the same should hold true for negligent acts that create the dependent risks of "people problems" in situations in-

116. Fancil v. Q.S.E. Foods, Inc., 60 Ill. 2d 552, 555, 328 N.E.2d 538, 541 (1975).

117. Id.

118. Negligence is the failure to use reasonable care. Though some courts frequently state that negligence requires a duty $\mathrm{m}$ addition to an unreasonable act, it is clear that im the absence of unreasonable conduct there can be no neghigence. See generally ProssER, supra note 2, at 143-49. 
volving police officers. ${ }^{119}$

The second type of situation in which injury results from more than one risk or party occurs when a police officer or firefighter is negligently injured by a third person while responding to a negligently created einergency or problem. If the action is maintained against the party whose negligence directly caused the injury, the risk is generally independent and can be resolved easily without consideration of the policies underlying the professional rescuers rule. When, lowever, the action is brought against the individual who negligently caused the original emergency or problem, and who was, therefore, only an indirect cause of the injury, the analysis becoines inore complex.

This type of inultiple party injury is presented in Schrimsher $v$. Bryson, ${ }^{120}$ a California case in which a police officer, responding to an automobile collision caused by the defendant, was struck by a third vehicle. The trial court granted summary judgment for defendant because it concluded that, as a matter of law, the defendant's previous negligence in causing the autornobile accident was not the proximate cause of the police officer's injuries. In affirming, the court of appeal concluded that the action of the third party driver was not foreseeable, and, therefore, was an intervening act that broke the chain of causation. 121

The Schrimsher court's proximate cause analysis led it to an unfortunate conclusion concerning the foreseeability of the accident. If the police officer had been an ordinary inotorist in the act of rescuing the defendant, the court likely would have had little difficulty finding the negligence of the third driver foreseeable and, therefore, a natural and ordinary consequence of defendant's neghient driving. ${ }^{122}$ The court also discussed the fireinan's rule, thus indicating soine awareness of the assuunption rationale. Reliance on a proximate cause analysis to dispose of the case, however, indicates confusion with the doctrine.

The professional rescuers rule, in contrast, would expressly acknowledge the policy reasons for the result reached in Schrimsher, and would avoid the confusion regarding proximate cause. Under the professional rescuers rule, any risks arising froin the circumstances of the

119. But see Enders v. Apcoa, Inc., 55 Cal. App. 3d 897, 127 Cal. Rptr. 751 (2d Dist. 1976). In Enders, the court held that a police officer has a cause of action against a parking lot operator who negligently permits a thief to steal a car from the lot, when the police officer is imjured in a collision between the officer's vehicle and the stolen vehicle. The court did not discuss the assumption rationale. A proper analysis in Enders would find the risk to be a dependent one, and recovery barred by the assumption rationale.

120. 58 Cal. App. 3d 660, 130 Cal. Rptr. 125 (2d Dist. 1976).

121. The court supported its decision with a discussion of the fireman's rule and with an observation that it would be an unwarranted extension of liability to hold the defendant responsible for injuries to traffic officers when the injuries are caused by third persons. Id. at $665-66,130$ Cal. Rptr. at 128.

122. See, e.g., Byrnes v. Stephens, 349 S.W.2d 611 (Tex. Civ. App. 1961). 
defendant who created the original einergency are dependent on the accident, because the defendant would pose no danger to the officer if the defendant's accident had not occurred. The third party, who struck the officer investigating the defendant's accident, creates an independent risk for which the third party is responsible. The third party poses the risk of collision to the officer whether or not the officer is assisting the defendant. Consequently, the third party owes a duty of reasonable care to the officer, and the defendant who created the original emergency is not liable. This analysis is applicable to any defendant whose negligence creates only the dependent risks of the specific einergency that professional rescuers are remedying when they are injured by the further negligence of a third party.

The third type of situation arises when the same party creates dependent and independent risks, both of which cause injury to the police officer or firefighter. In situations involving both types of risks, several doctrines are involved in defining the scope of duty. Dependent risks are controlled by doctrines founded on the assumption rationale, whereas independent risks are controlled by ordinary rules governing duty. Liability for injuries caused by both dependent and independent risks may be easily resolved if the dependent risk is extraordmary or blamewortly, because reasonable care is the standard required by both doctrines. Difficulties arise, however, when both ordinary dependent and independent risks cause injury, because in the former situation no duty exists, whereas in the latter instance the tortfeasor usually owes a duty of reasonable care. ${ }^{123}$

If a police officer or firefighter could recover full coinpensation for injuries caused by botli dependent and independent risks, despite the extent to which the injury was caused by the forner risk, the purpose and effect of a professional rescuers rule could be defeated by simply alleging that the injury was caused by inultiple risks. ${ }^{124}$ On the other hand, officers slould not be denied recovery for injuries caused by independent risks, and negligent defendants should not be given an opportunity to prevent recovery entirely through proof that the injury was caused in part by dependent risks.

This dilemnna could be resolved by apportioning the damages according to the degree to which the dependent and independent risks caused the injury, permitting recovery for the portion caused by the

123. No duty is owed to the professional rescuer for independent risks for which the jurisdiction does not impose a general duty. See note 90 supra.

124. The purpose of the assuinption rationale is to limit recovery by contracting risk takers. When the rule is expressed as a lack of duty, a judge can grant a pretrial dismissal of the action and thereby rednce the cost of litigation. If the professional rescuer can rccover for all injurics by joining an allegation that the injury was caused in part by an independent risk, the suit has a settleinent value and is no longer as easily subject to pretrial disposition. 
independent risk. Under this proposed system, the judge, in cases where the relevant facts are uncontested, would determine whether independent or dependent risks were posed by the emergency. The factfinders would then be imstructed to apportion damages in relation to the degree that each of the types of risks are found to have caused the professional rescuers' injuries.125 If the relevant facts are contested, the judge would determine whether a dependent or independent risk is posed under each resolution of the facts, and instruct the factfinders in the alternative as to the consequences of the possible resolutions.

\section{CONCLUSION}

The proposed professional rescuers rule provides that: (1) A person is not hable to professional rescuers for injuries caused to them by risks dependent on the specific einergency or problein encountered by the professional rescuers unless the dependent risk is extraordinary or blameworthy; ${ }^{126}$ and (2) a person owes a duty of reasonable care to professional rescuers for independent risks that the person causes, unless the jurisdiction generally imposes no duty on any person for this type of risk or injury.

The law governing tort recovery by police officers and firefighters is currently uncertain because of changing conceptions of the role of these officers in society, and because of developments in the doctrines of assumption of risk and owner and occupier duty. Courts have struggled to permit or deny recovery under a variety of theories. While the results are generally sound, the opimions have frequently distorted existing doctrines to reach those results. The proposed rule integrates the various competing doctrines into a single framework that should eliminate the present confusion.

Richard D. Zimmerman*

125. A rule of comparative causation would differ little from a rule of comparative negligence. In the former, damages are apportioned according to the injury caused by different risks created by the same person; whereas in the latter, the risks are caused by different persons.

126. The proposed rule, of course, would not bar recovery for intentional torts, regardless of the relation of the risk to the task of the professional rescuer. See note 19 supra.

* A.B. 1974, Harvard College; third-year student, Boalt Hall School of Law. 
